\title{
Hubungan Pendidikan, Paritas dan Dukungan Kader dengan Deteksi Dini Kanker Serviks Pada Pemeriksaan IVA di Puskesmas Nagaswidak Palembang Tahun 2021
}

\author{
Marina Yanti ${ }^{1}$, Eka Rahmawati ${ }^{2}$, Putu Lusita ${ }^{3}$, Tuti Farida ${ }^{\mathbf{4}}$ \\ Universitas Kader Bangsa Palembang ${ }^{1,2,3,4}$
}

\section{A B S T R A K}

Informasi Artikel :

Diterima : 28 Oktober 2021

Direvisi : 02 November 2021

Disetujui : 20 Desember 2021

Diterbitkan : 30 Desember 2021

*Korespondensi Penulis : marinayanti1987@gmail.com
Kanker serviks dan payudara merupakan penyebab kematian cukup tinggi pada perempuan, umumnya wanita usia produktif mulai dari 30-50 tahun. Tujuan penelitian ini adalah untuk mengetahui hubungan pendidikan, paritas dan dukungan kader secara simultan dengan deteksi dini kanker serviks pada pemeriksaan IVA Di Puskesmas Nagaswidak Palembang Tahun 2021. Desain penelitian ini menggunakan metode survey analitik dengan pendekatan cross sectional. Populasi berjumlah 84 responden dan jumlah sampel dalam penelitian ini adalah sebanyak 84 responden. Pengambilan sampel penelitian dengan menggunakan Jumlah sampling. Pengumpulan data dengan menggunakan data primer dan sekunder. Hasil penelitian analisis univariat responden yang mengalami Deteksi Dini Kanker Serviks berjumlah 59 orang (70.2\%), Pendidikan tinggi berjumlah 46 orang (54.8\%), paritas tidak berisiko 50 orang (59.5\%), Dukungan Kader berjumlah 56 orang (66.7\%). Hasil analisis bivariat ada hubungan bermakna antara pendidikan terhadap deteksi dini kanker serviks dengan nilai $p$ value sebesar $0,000<0,05$, paritas terhadap deteksi dini kanker serviks dengan nilai $p$ value sebesar $0,033<0,05$, dan dukungan kader terhadap terdeteksi dini kanker serviks dengan nilai $p$ value sebesar $0,002<0,05$ secara simultan dengan kejadian deteksi dini kanker serviks pada pemeriksaan IVA Di Puskesmas Nagaswidak Palembang Tahun 2021. Kesimpulan penelitian ini adalah ada hubungan pendidikan, paritas dan dukungan kader secara simultan dengan deteksi dini kanker serviks pada pemeriksaan IVA Di Puskesmas Nagaswidak Palembang Tahun 2021. Adapun saran bagi petugas kesehatan hasil penelitian ini diharapkan agar petugas kesehatan di Puskesmas Nagaswidak Palembang, dapat dengan siaga memberikan informasi dan edukasi kepada wanita usia subur terkait kesehatannya khususnya kesehatan reproduksi.

Kata Kunci : Kanker Serviks, Paritas, Pendidikan, Dukungan Kader

ABSTRACT

Cervical and breast cancers are fairly high causes of death in women, generally women of productive ages ranging from 30-50 years. The goal of this study was to find out the relationship of education, parity and cadre support simultaneously with the early detection of cervical cancer at the AVI examination at the Puskesmas Nagaswidak Palembang in 2021. The design of this 
study used the analytical survey method with the cross sectional approach. The population consisted of 84 respondents and the number of samples in this study included 84 respondents. Sampling research used the Jumlah sampling. Data collection used the primary and secondary data. The results of the univariate analysis showed that the respondents who had the early detection of cervical cancer were 59 people (70.2\%), those with higher education were 46 people (54.8\%), those with parity not at risk were 50 people $(59.5 \%)$, and those with cadre support were 56 people (66.7\%). The results of the bivariate analysis showed a significant relationship between education and early detection of cervical cancer with the $p$ value of $0.000<0.05$, parity to early detection of cervical cancer with the $p$ value of $0.033<0.05$, and cadre support for early detection of cervical cancer with the $p$ value of $0.002<0.05$ simultaneously with the incidence of early detection of cervical cancer at the AVI examination at Puskesmas Nagaswidak Palembang in 2021.The conclusion of this study is that there is a relationship between education, parity and cadre support simultaneously with the early detection of cervical cancer at the AVI examination at Puskesmas Nagaswidak Palembang in 2021. It is recommended that from the results of this study the health workers at Puskesmas Nagaswidak Palembang are readily able to give information and education to women of childbearing ages regarding their health, especially the reproduction health.

\section{Keywords :Cervical Cance, Parity, Education, Cadre Support}

\section{PENDAHULUAN}

Kanker serviks adalah kanker dengan angka kejadian nomer empat terbanyak yang terjadi pada wanita diseluruh dunia, dengan perkiraan 570.000 kasus baru pada tahun 2018 dan mewakili 6,6\% dari semua kanker pada wanita. Sekitar $90 \%$ kematian akibat kanker serviks terjadi di negara-negara berpenghasilan rendah dan menengah. Tingkat kematian yang tinggi dari kanker serviks secara global dapat dikurangi melalui pendekatan komprehensif yang mencakup pencegahan, diagnosis dini, skrining yang efektif dan program pengobatan. (WHO, 2018).

Kanker seviks adalah salah satu penyumbang angka kematian pada perempuan yang cukup tinggi di mana kondisi ini mayoritas terjadi di negara-negara berkembang. Berdasarkan data Global Burden Cancer atau Interntional Agency for Research on Cancer (IARC) diketahui bahwa penyebab kematian tertinggi setelah kanker payudara adalah kanker serviks yang merupakan kanker ginekologi penyumbang penyebab kematian tertinggi pada wanita. (Globocan 2018).

Berdasarkan data Riskesdas (2018), prevalensi kanker di Indonesia menunjukkan adanya peningkatan dari 1.4 per 1000 penduduk di tahun 2013 menjadi 1,79 per 1000 penduduk pada tahun 2018. Prevalensi kanker tertinggi adalah di provinsi DI Yogyakarta 4,86 per 1000 penduduk, diikuti Sumatera Barat 2,47 79 per 1000 penduduk dan Gorontalo 2,44 per 1000 penduduk. (Riskesdas (2018).

Berdasarkan data Dinas Kesehatan Provinsi Sumatera Selatan sebanyak 1.870 


\section{Jurnal Kebidanan : Jurnal Medical Science Ilmu Kesehatan Akademi Kebidanan Budi Mulia Palembang Volume.11 No.2, Desember 2021 \\ Available online https://iournal.budimulia.ac.id/}

dari 5.226 perempuan di Sumatera Selatan terdeteksi mengindap kanker serviks dan kanker payudara, hasil pemeriksaan yang dilakukan sejak tahun 2015 terhadap 5.226 perempuan, ternyata 1.870 diantaranya terdeteksi kanker serviks dan payudara. (Dinas Kesehatan, 2016).

Menurut data Dinkes Provinsi Sumatera Selatan mengatakan, Provinsi Sumatera Selatan menargetkan 344 ribu perempuan dan ibu-ibu untuk dilakukan pemeriksaan. Kanker serviks dan payudara merupakan penyebab kematian cukup tinggi pada perempuan, umumnya wanita usia produktif mulai dari 30-50 tahun, kalangan perempuan sangat rentan terkena kanker serviks dan payudara apabila tidak menjaga kebersihan organ intimnya dengan demikian virus pembawa penyakit tersebut dapat dengan gampang datang. (Dinas Kesehatan Provinsi Sumatera Selatan, 2016).

Berdasarkan data dari DinasKesehatan Provinsi Sumatera Selatan Tahun 2018. Jumlah angka kejadian kanker serviks adalah sebanyak 1.544 kasus dan pada laporan tahunan Dinas Kesehatan Kota Palembang tahun 2018 angka kejadian kanker serviks adalah 797 kasus. (Dinas Kesehatan Provinsi Sumatera Selatan, 2018).

Data Dinas Kesehatan Kota Palembang di bulan Januari 2017 dalam rekapitulasi deteksi dini kanker leher rahim didapatkan ibu dengan usia 40-50 tahun berjumlah 1 orang, usia $>50$ tahun berjumlah 1 orang. (Dinas Kesehatan Kota Palembang, 2017).

Menurut data dari Dinas Kesehatan Kota Palembang, pada tahun 2018 jumlah WUS yang diperiksa IVA sebanyak 7.320 $(2,8 \%)$ dimana ditemukan 181(2,5\%) IVA positif. (Profil Dinkes Palembang, 2018). Cakupan pemeriksaan IVA meningkat di Tahun 2019 yaitu sebanyak 13260 WUS telah diperiksa IVA dengan hasil 175 (1,32\%) IVA positif (Dinkes Kota Palembang, 2019). Namun pada tahun 2020 cakupan pemeriksaan IVA kembali menurun menjadi $5846(2,17 \%)$ dimana ditemukan 77 IVA positif (1,32\%). (Dinkes Kota Palembang, 2020).

Berdasarkan data di rekam medik di Puskesmas Nagaswidak Palembang, didapatkan wanita usia subur berjumlah 6706orang,yang melakukan pemeriksaan IVA pada tahun 2018 berjumlah 81 (1,21 persen) tidak ada yang terdeteksi positif kanker serviks, pada tahun 2019 yang melakukan pemeriksaan IVA berjumlah 122 (1,82 persen) terdeteksi positif kanker serviks berjumlah 1 orang, pada tahun 2020 yang melakukan pemeriksaan IVA berjumlah 103 (1,54 persen) terdeteksi positif kanker serviks berjumlah 2 orang, pada tahun 2021 dari bulan Januari sampai dengan bulan Juni yang melakukan pemeriksaan IVA berjumlah 84 (11,5 persen) tidak ada yang terdeteksi positif kanker serviks. (Rekam Medik Puskesmas Nagaswidak, 2021).

Nutrition and Cancer menemukan bahwa orang-orang yang mengonsumsi makanan kaya antioksidan, flavonoid, folat, karotenoid, vitamin $\mathrm{C}$, vitamin $\mathrm{E}$ dan serat mengalami penurunan risiko kanker serviks sebesar 40 hingga 60 persen. Zat-zat tersebut dapat membantu membersihkan infeksi HPV lebih cepat dengan menghambat perubahan sel-sel leher rahim menjadi sel kanker. Manfaat zat-zat tersebut bisa Anda dapatkan dengan mengonsumsi buah-buahan, sayursayuran, kacang-kacangan, dan biji-bijian. Beberapa contoh sayuran penurun risiko kanker serviks adalah brokoli, kubis, bawang putih, bawang merah, selada, bayam, wortel, ubi jalar, labu. Daftar buah yang bisa dikonsumsi adalah alpukat, apel, stroberi, jus jeruk, teh hijau juga dapat membantu mencegah terkena kanker serviks. Sekitar 30 sampai 40 persen kanker dapat dicegah dengan perubahan pola makan dan gaya hidup. Meskipun tidak ada makanan tertentu yang bisa mencegah kanker serviks, namun 
beberapa gaya hidup sehat dapat membantu menurunkan risiko terkena kanker serviks.(Savitri, 2018 ).

Faktor - faktor yang mempengaruhi terjadinya kanker serviks adalah pekerjaan, pendidikan, usia, penyakit menular seksual, kontrasepsi hormonal, paritas, usia pertama kali berhubungan seksual, berganti pasangan, merokok, Human Papiloma Virus ( $H P V)$. (Rukiyah ,2018).

Faktor - faktor yang mempengaruhi WUS dalam melakukan IVA Tes adalah pengetahuan, sikap, dukungan suami, dukungan kader. (Nurjanah, 2019).

Deteksi dini kanker leher rahim dilakukan pada kelompok sasaran perempuan 20 tahun ke atas, namun prioritas program deteksi dini di Indonesia pada perempuan usia 30-50 tahun dengan target 50\% perempuan sampai tahun 2019. Untuk IVA dilakukan minimal 3 tahun sekali. (Direktorat Pengendalian Penyakit Tidak Menular Kementerian Kesehatan RI, 2015).

Pendidikan tinggi akan mempengaruhi pola pikir seseorang untuk mengambil keputusan. Begitu juga dengan keputusan yang berhubungan dengan kesehatan seseorang. Dengan pendidikan yang tinggi, maka semakin banyak informasi yang seharus bisa ia dapatkan, bisa melalui lingkungan tempat ia bekerja, media elektronik, media sosial, tenaga kesehatan dan juga teman dan anggota keluarga terdekat. (Arimurti, 2020).

Penelitian Arimurti, 2020, yang berjudul hubungan pendidikan dengan perilaku deteksi dini kanker serviks pada wanita di Kelurahan Kebon Kalapa Bogor, analisis hasil pengolahan data menunjukkan terdapat hubungan yang bermakna antara pendidikan dan perilaku deteksi dini kanker serviks ( $p$ value 0,000 ). Dimana wanita yang pendidikannya menengah berpeluang 5,3 kali melakukan deteksi dini. (Arimurti, 2020).
Paritas bukan sebuah patokan untuk mendasari seseorang melakukan Pap Smear dan IVA. Selain itu, adanya anggapan pada masyarakat yang menganggap kalau deteksi dini seperti Pap Smear dan IVA bukanlah suatu hal yang yang mendasar. Berdasarkan hasil penelitian, teori, dan penelitian terkait bahwa paritas tidak ada hubungan dengan pemilihan metode Pap Smear. Hal ini dikarenakan ketidaktahuan tentang metode Pap Smear ataupun IVA itu sendiri dan dianggap sebagai suatu hal yang tabu. Adanya perbedaan pendapat mengenai paritas mungkin disebabkan oleh adanya perbedaan kondisi masyarakat, seperti tingginya arus informasi yang diterima masyarakat setempat, pola hidup masyarakat,kondisi geografis serta perbedaan karakteristik penduduk. (Rosdiana, 2019).

Penelitian Adam, 2017 yang berjudul Hubungan Usia, Paritas Dan Personal Hygiene Dengan Hasil Pemeriksaan Inspeksi Visual Asam Asetat (Iva) Di Puskesmas Brangsong 2 Kecamatan Brangsong Kabupaten Kendal hasil uji statistik Chi Square menunjukkan nilai $\mathrm{p} \leq 0,05$, berarti H0 ditolak dan H1 diterima, disimpulkan adanya hubungan bermakna antara paritas dengan hasil pemeriksaan IVA, memiliki banyak anak (lebih dari 5) menambah faktor resiko kanker serviks. (Adam, 2017).

Kader peduli kanker serviks memberikan pengaruh emosional dan persuasif terhadap pemberdayaan wanita dalam melakukan deteksi dini kanker serviks. Kader dapat menjadi fasilitator antara tenaga kesehatan dan masyarakat dalam meningkatkan sikap dan partisipasi wanita untuk melakukan pemeriksaan IVAataupun papsmear. (Setyani, 2018).

Penelitian Wulan, 2019 yang berjudul hubungan dukungan dengan minat wanita usia subur dalam melakukan pemeriksaan IVA di Dusun Milir Jimbaran Kabupaten Semarang ini juga menunjukan hasil uji 
statistik diproleh nilai $\mathrm{p}$ value 0,017 sehingga dapat disimpulkan bahwa ada hubungan antara dukungan kader dengan minat wanita usia subur dalam melakukan pemeriksaan IVA di Dusun Milir Kecamatan Jimbaran Kabupaten Semarang. (Wulan, 2019).

Berdasarkan data diatas, maka penulis tertarik untuk melakukan penelitian tentang laporan "Hubungan pendidikan, paritas dan dukungan kader dengan deteksi dini kanker serviks pada pemeriksaan IVA di Puskesmas Nagaswidak Palembang Tahun 2021".

\section{METODE PENELITIAN}

Penelitian ini menggunakan metode survey analitik dengan menggunakan pendekatan secara cross sectional dimana variabel independen (Pendidikan, Paritas dan Dukungan Kader) dan variabel dependen (Deteksi Kanker Serviks) diambil pada waktu yang bersamaan. (Notoatmodjo,2010).

Penelitian ini telah dilaksanakan pada bulan Juli- Agustus 2021

Lokasi penelitian telah dilaksanakan di Puskesmas Nagaswidak Palembang dengan Alamat : Jln. A.Yani Lorong Gumay Gang Bangdesh Kelurahan 14 Ulu Kecamatan Seberang Ulu Dua Kota Palembang 30264.

Populasi adalah keseluruhan objek yang akan diteliti (Notoatmodjo,2017). Populasi pada peneliti adalah seluruh wanita usia subur yang berpasangan yang berkunjung saat kegiatan posbindu PTM di wilayah kerja Puskesmas Nagaswidak Palembang pada tahun 2021 pada bulan Januari sampai dengan bulan Mei yang berjumlah 84 orang.

Sampling adalah suatu cara yang ditempuh dengan pengambilan sampel yang benar-benar sesuai dengan keseluruhan obyek penelitian (Nursalam, 2008). Teknik pengambilan sampel pada penelitian ini dengan menggunakan Jumlah sampling. Jumlah Sampling adalah teknik pengambilan sampel dimana jumlah sampel sama dengan jumlah populasi (Sugiyono, 2007). Alasan mengambil Jumlah sampling karena jumlah populasi yang kurang dari 100 maka seluruh populasi dijadikan sampel penelitian semuanya (Sugiyono, 2007). Jadi jumlah sampel penelitian ini adalah 84 orang.

Pengumpulan data dalam penelitian ini menggunakan data primer dan sekunder. Yang mana data sekunder diperoleh dari laporan bulanan penanggung jawab program IVA dan catatan rekam medic di Puskesmas Nagaswidak Palembang tahun 2021 pada bulan januari sampai dengan mei.Instrumen pengumpulan data pada penelitian ini menggunakan lembar Kuesioner pada variabel dukungan kader.

Data yang diperoleh dalam penelitian akan disajikan dalam bentuk tabel lalu dilakukan analisa data secara univariat dan bivariat dengan melihat persentase data yang terkumpul. (Notoatmodjo,2010).

Pada penelitian ini data dianalisis dengan menggunakan tabel frekuensi yang dilakukan setiap variabel, yaitu variabel independen (pendidikan, paritas dan dukungan kader) dan variabel dependen. (deteksi dini kanker serviks).

Untuk mengetahui hubungan variabel independen dengan variabel dependen dengan dilakukan Uji Chi-Square, dengan batasan kemaknaan $\alpha$ : 0,05.

\section{HASIL PENELITIAN}

Karakteristik responden berdasarkan pendidikan, paritas, dan dukungan kader dengan deteksi dini kanker serviks pada pemeriksaan IVA di Puskesmas Nagaswidak Palembang Tahun 2021.

Tabel 1. Distribusi Frekuensi Responden Berdasarkan Kejadian Deteksi Dini Kanker Serviks di Puskesmas Nagaswidak

Palembang Tahun 2021 
Jurnal Kebidanan : Jurnal Medical Science Ilmu Kesehatan Akademi Kebidanan Budi Mulia Palembang Volume.11 No.2, Desember 2021

Available online https://journal.budimulia.ac.id/

\begin{tabular}{ccc}
\hline $\begin{array}{c}\text { Deteksi Dini } \\
\text { Kanker Serviks }\end{array}$ & Frekuensi & \% \\
\hline Ya & 59 & 70.2 \\
\hline Tidak & 25 & 29.8 \\
\hline Jumlah & 84 & 100 \\
\hline
\end{tabular}

Pada Tabel 1. Distribusi Frekuensi Responden Berdasarkan kejadian deteksi dini kanker serviks di Puskesmas Nagaswidak Palembang Tahun 2021 dapat disimpulkan bahwa lebih dari setengah responden yang terdeteksi dini kanker serviks berjumlah 59 orang $(70.2 \%)$.

Tabel 2. Distribusi Frekuensi Responden Berdasarkan Pendidikan di Puskesmas Nagaswidak Palembang Tahun 2021

\begin{tabular}{lcc}
\hline Pendidikan & Frekuensi & \% \\
\hline Tinggi & 46 & 54.8 \\
\hline Rendah & 38 & 45.2 \\
\hline Jumlah & 84 & 100
\end{tabular}

Pada Tabel 2, Distribusi Frekuensi Responden Berdasarkan pendidikan di Puskesmas Nagaswidak Palembang Tahun 2021 dapat disimpulkan bahwa lebih dari setengah responden yang berpendidikan tinggi berjumlah 46 orang $(54.8 \%)$
Tabel 3. Distribusi Frekuensi Responden Berdasarkan Paritas di Puskesmas Nagaswidak Palembang Tahun 2021

\begin{tabular}{|c|c|c|}
\hline Paritas & Frekuensi & $\%$ \\
\hline Tidak Beresiko & 50 & 59.5 \\
\hline Berisiko & 34 & 40.5 \\
\hline Jumlah & 84 & 100 \\
\hline
\end{tabular}

Responden Berdasarkan paritas di puskesmas Nagaswidak Palembang Tahun 2021 dapat disimpulkan bahwa lebih dari setengah responden dengan paritas tidak berisiko berjumlah 50 orang $(59.5 \%)$.

Tabel 4 Distribusi Frekuensi Responden Berdasarkan Dukungan Kader di Puskesmas Nagaswidak Palembang Tahun 2021

\begin{tabular}{|c|c|c|}
\hline Dukungan Kader & Frekuensi & $\%$ \\
\hline Mendukung & 56 & 66.7 \\
\hline Tidak mendukung & 28 & 33.3 \\
\hline Jumlah & 84 & 100 \\
\hline $\begin{array}{l}\text { Pada Tabel 4, } \\
\text { Responden Berdasarka } \\
\text { Puskesmas Nagaswid } \\
2021 \text { dapat disimpull } \\
\text { setengah responden } \\
\text { kader berjumlah } 56 \text { ora }\end{array}$ & $\begin{array}{l}\text { Distribusi } \\
\text { n Dukungan } \\
\text { k Palemban } \\
\text { an bahwa } 1 \\
\text { mendapat } \\
\text { ng }(66.7 \%) \text {. }\end{array}$ & $\begin{array}{l}\text { ekuen } \\
\text { ader } \\
\text { Tahu } \\
\text { ih da } \\
\text { kunga }\end{array}$ \\
\hline
\end{tabular}

Tabel 5. Hubungan Pendidikan dengan Kejadian Deteksi Dini Kanker Serviks di Puskesmas Nagaswidak Palembang Tahun 2021

\begin{tabular}{|c|c|c|c|c|c|c|c|c|}
\hline \multirow{3}{*}{ Pendidikan } & \multicolumn{4}{|c|}{$\begin{array}{c}\text { Deteksi Dini } \\
\text { Kanker Serviks }\end{array}$} & \multirow{2}{*}{\multicolumn{2}{|c|}{ Jumlah }} & \multirow[t]{2}{*}{ p-value } & \multirow{2}{*}{$\begin{array}{c}\text { OR(95\% } \\
\text { CI) }\end{array}$} \\
\hline & & Ya & & & & & & \\
\hline & $\mathbf{n}$ & $\%$ & n & $\%$ & $\mathbf{N}$ & $\%$ & \multirow[b]{2}{*}{0,000} & 77.143 \\
\hline Tinggi & 45 & $97.8 \%$ & 1 & $2.2 \%$ & 46 & $100 \%$ & & (9.557- \\
\hline
\end{tabular}


Jurnal Kebidanan : Jurnal Medical Science Ilmu Kesehatan Akademi Kebidanan Budi Mulia Palembang Volume.11 No.2, Desember 2021

Available online https://journal.budimulia.ac.id/

\begin{tabular}{ccccccc}
\hline \hline Rendah & 14 & $36.8 \%$ & 24 & $63.2 \%$ & 38 & $100 \%$ \\
\hline Jumlah & 59 & & 25 & & 84 & $622.676)$ \\
\end{tabular}

Berdasarkan dari tabel 5. diatas menunjukkan persentase responden berpendidikan tinggi terdeteksi dini kanker serviks sebanyak 45 orang (97.8\%) dan yang tidak terdeteksi dini kanker serviks sebanyak 1 orang (2.2\%). Sedangkan reponden berpendidikan rendah terdeteksi dini kanker serviks sebanyak 14 orang $(36.8 \%)$ dan yang tidak terdeteksi dini kanker servikssebanyak 24 orang (63.2\%). Hasil uji statistik menggunakan chi-square menunjukkan terdapat hubungan yangsignifikan antara pendidikan terhadap deteksi dini kanker serviks dengan nilai $p$ value sebesar $0,000<0,05$.

Tabel 6. Hubungan Paritas dengan Kejadian Deteksi Dini Kanker Serviks di Puskesmas Nagaswidak Palembang Tahun 2021

\begin{tabular}{|c|c|c|c|c|c|c|c|c|}
\hline \multirow{3}{*}{ Paritas } & \multicolumn{4}{|c|}{$\begin{array}{c}\text { Deteksi Dini } \\
\text { Kanker Serviks }\end{array}$} & \multirow{2}{*}{\multicolumn{2}{|c|}{ Jumlah }} & \multirow{3}{*}{ p-value } & \multirow{3}{*}{$\begin{array}{c}\text { OR(95\% } \\
\text { CI })\end{array}$} \\
\hline & \multicolumn{2}{|c|}{ Ya } & \multicolumn{2}{|c|}{ Tidak } & & & & \\
\hline & n & $\%$ & $\mathbf{n}$ & $\%$ & $\mathbf{N}$ & $\%$ & & \\
\hline $\begin{array}{c}\text { Tidak } \\
\text { Berisiko }\end{array}$ & 40 & $80.0 \%$ & 10 & $20.0 \%$ & 50 & $100 \%$ & $\mathbf{0 , 0 3 3}$ & $\begin{array}{c}3.158 \\
(1.199-\end{array}$ \\
\hline Beresiko & 19 & $55,9 \%$ & 15 & $44,1 \%$ & 34 & $100 \%$ & & 8.320) \\
\hline Jumlah & 59 & & 25 & & 84 & & & \\
\hline
\end{tabular}

Berdasarkan dari tabel 6 diatas menunjukkan persentase responden paritas yang tidak berisiko terdeteksi dini kanker serviks sebanyak 40 orang $(80.0 \%)$ dan yang tidak terdeteksi dini kanker serviks sebanyak 10 orang $(20.0 \%)$. Sedangkan responden dengan paritas yang berisiko terdeteksi dini kanker serviks sebanyak 19 orang (55.9\%) dan yang tidak terdeteksi dini kanker serviks sebanyak 15 orang (44.1\%). Hasil uji statistik menggunakan chi-square menunjukkan terdapat hubungan yang signifikan antara paritas terhadap deteksi dini kanker serviks dengan nilai $p$ value sebesar $0,033<0,05$.

Tabel 7. Hubungan Dukungan Kader dengan Kejadian Deteksi Dini Kanker Serviks di Puskesmas Nagaswidak Palembang Tahun 2021

\begin{tabular}{|c|c|c|c|c|c|c|c|c|}
\hline \multirow{3}{*}{ Dukungan Kader } & \multicolumn{4}{|c|}{$\begin{array}{c}\text { Deteksi Dini } \\
\text { Kanker Serviks }\end{array}$} & \multirow{2}{*}{\multicolumn{2}{|c|}{ Jumlah }} & \multirow{3}{*}{ p-value } & \multirow{2}{*}{$\begin{array}{c}\text { OR(95\% } \\
\text { CI })\end{array}$} \\
\hline & \multicolumn{2}{|c|}{ Ya } & \multicolumn{2}{|c|}{ Tidak } & & & & \\
\hline & $\mathbf{n}$ & $\%$ & $\mathbf{n}$ & $\%$ & $\mathbf{N}$ & $\%$ & & \\
\hline Mendukung & 46 & $82.1 \%$ & 10 & $17.9 \%$ & 56 & $100 \%$ & & \\
\hline $\begin{array}{c}\text { Kurang } \\
\text { Mendukung }\end{array}$ & 13 & $46.4 \%$ & 15 & $53.6 \%$ & 28 & $100 \%$ & 0,002 & $\begin{array}{c}5.308 \\
(1.934- \\
14.567)\end{array}$ \\
\hline Jumlah & 59 & & 25 & & 84 & & & \\
\hline
\end{tabular}




\section{Jurnal Kebidanan : Jurnal Medical Science Ilmu Kesehatan Akademi Kebidanan Budi Mulia Palembang Volume.11 No.2, Desember 2021 \\ Available online https://iournal.budimulia.ac.id/}

Berdasarkan dari table 7 diatas menunjukkan persentase responden yang mendapat dukungan kader terdeteksi dini kanker serviks sebanyak 46 orang (82.1\%) dan yang tidak terdeteksi dini kanker serviks sebanyak 10 orang (17.9\%). Sedangkan kurang mendapat dukungan kader terdeteksi dini kanker serviks sebanyak 13 orang (46.4\%) dan yang tidak sebanyak 15 orang (53.6\%). Hasil uji statistik menggunakan chi-square menunjukkan terdapat hubungan yang signifikan antara dukungan kader terhadap terdeteksi dini kanker serviksdengan nilai $p$ value sebesar $0,002<0,05$.

\section{PEMBAHASAN}

Berdasarkan penelitian yang telah dilakukan di Puskesmas Nagaswidak Tahun 2021, dimana deteksi dini kanker serviks dibagi menjadi 2 kategori yaitu ya dan tidak. Berdasarkan analisis univariat, table 1, Distribusi Frekuensi Responden Berdasarkan kejadian deteksi dini kanker serviks di Puskesmas Nagaswidak Palembang Tahun 2021 dapat disimpulkan bahwa lebih dari setengah responden yang terdeteksi dini kanker serviks berjumlah 59 orang $(70.2 \%)$.

Berdasarkan penelitian yang telah dilakukan di Puskesmas Nagaswidak Tahun 2021, dimana pendidikan dibagi menjadi 2 kategori yaitu tinggi dan rendah. Berdasarkan analisis univariat, Tabel 2, Distribusi Frekuensi Responden Berdasarkan pendidikan

di Puskesmas Nagaswidak Palembang Tahun 2021 dapat disimpulkan bahwa lebih dari setengah responden yang berpendidikan tinggi berjumlah 46 orang $(54.8 \%)$.

Berdasarkan analisis bivariat, tabel 5 diatas menunjukkan persentase responden berpendidikan tinggi terdeteksi dini kanker serviks sebanyak 45 orang $(97.8 \%)$ dan yang tidak terdeteksi dini kanker servikssebanyak 1 orang (2.2\%). Sedangkan reponden berpendidikan rendah terdeteksi dini kanker serviks sebanyak 14 orang $(36.8 \%)$ dan yang tidak terdeteksi dini kanker serviks sebanyak 24 orang (63.2\%). Hasil uji statistik menggunakan chi-square menunjukkan terdapat hubungan yang signifikan antara pendidikan terhadap deteksi dini kanker serviks dengan nilai $p$ value sebesar $0,000<$ 0,05 .
Penelitian ini sejalan dengan teori bahwa hasil ukur yang digunakan untuk pendidikan adalah pendidikan rendah jika pendidikan responden dari SD sampai SMP dan pendidikan tinggi jika pendidikan responden dari SMA sampai perguruan tinggi. (Winarni, 2020).

Penulis menyimpulkan bahwa tingkat pendidikan yang dimiliki peserta pemeriksaan IVA ini menggambarkan bahwa ibu - ibu peserta IVA cukup memiliki kemampuan intelektual yang tertuju mempengaruhi berbagai aktivitas dan berpikir memecah masalah, sehingga dapat diasumsikan bahwa ibu - ibu peserta pemeriksaan IVA memiliki pengetahuan yang cukup tentang pentingnya pemeriksaan IVA atau pentingnya deteksi dini terhadap kanker leher rahim. Pendidikan memiliki kontribusi yang cukup besar terhadap pengetahuan seseorang dalam pengambilan keputusan, makin tingginya pendidikan seorang ibu, semakin mudah dalam mendapatkan informasi mengenai kesehatannya.

Berdasarkan penelitian yang telah dilakukan di Puskesmas Nagaswidak Tahun 2021. Dimana paritas dibagi menjadi 2 kategori yaitu berisiko dan tidak berisiko. Berdasarkan analisis univariat, Tabel 4, Distribusi Frekuensi Responden Berdasarkan paritasdi Puskesmas Nagaswidak Palembang Tahun 2021 dapat disimpulkan bahwa lebih dari setengah responden dengan paritas tidak berisiko berjumlah 50 orang (59.5\%).

Berdasarkan analisis bivariat, table 6 diatas menunjukkan persentase responden paritas yang tidak berisiko terdeteksi dini kanker servikssebanyak 40 orang (80.0\%) dan 
yang tidak terdeteksi dini kanker serviks sebanyak 10 orang $(20.0 \%)$. Sedangkan responden dengan paritas yang berisiko terdeteksi dini kanker serviks sebanyak 19 orang $(55.9 \%)$ dan yang tidak terdeteksi dini kanker serviks sebanyak 15 orang (44.1\%).Hasil uji statistik menggunakan chisquaremenunjukkan terdapat hubungan yang signifikan antara paritas terhadap deteksi dini kanker serviks dengan nilai $p$ value sebesar $0,033<0,05$.

Penelitian ini sejalan dengan teori bahwa insiden meningkat dengan tingginya paritas, jarak persalinan yang terlampau dekat. Diperkirakan risiko 3-5 kali lebih besar pada wanita yang sering partus untuk terjadi kanker serviks. Robekan pada bagian leher rahim yang tipis kemungkinan dapat menyebabkan timbulnya suatu peradangan dan selanjutnya berubah menjadi kanker. Paritas merupakan keadaan dimana seorang wanita pernah melahirkan. Paritas yang berbahaya adalah dengan memiliki jumlah anak lebih dari 2 orang atau jarak persalinan terlampau dekat. Sebab dapat menimbulkan perubahan sel-sel abnormal pada mulut rahim dan dapat berkembang menjadi keganasan. (Bertiani, 2013).

Penulis menyimpulkan bahwa wanita dengan paritas tinggi dapat menyebabkan trauma pada jalan lahir, jumlah anak yang dilahirkan melalui jalan normal dapat menyebabkan terjadinya perubahan sel abnormal dari epitel dan dapat berkembang menjadi keganasan. Oleh karena itu, sebagai tenagakesehatan perlu menumbuhkan kesadaran diri pada wanita dalam melakukan deteksi dini terhadap kanker serviks serta berperilaku hidup sehat dan bersih. Jika pada pemeriksaan awal ibu tidak terkena kanker serviks maka dapat dilakukan pencegahan dengan vaksinasi. Namun bagi ibu yang sudah terkena kanker serviks maka harus segera diberikan pelayanan kesehatan sesuai dengan stadium yang diderita untuk mencegah terjadinya metase. (penyebaran ke organ lain).

Berdasarkan penelitian yang telah dilakukan di Puskesmas Nagaswidak Tahun 2021. Dimana dukungan kader dibagi menjadi 2 kategori yaitu mendukung dan kurang mendukung. Berdasarkan analisis bivariat, Tabel 5.4, Distribusi Frekuensi Responden Berdasarkan Dukungan Kader di Puskesmas Nagaswidak Palembang Tahun 2021 dapat disimpulkan bahwa lebih dari setengah responden mendapat dukungan kader berjumlah 56 orang $(66.7 \%)$.

Berdasarkan analisis bivariat, tabel 5.7 diatas menunjukkan persentase responden yang mendapat dukungan kader terdeteksi dini kanker serviks sebanyak 46 orang $(82.1 \%)$ dan yang tidak terdeteksi dini kanker serviks sebanyak 10 orang (17.9\%). Sedangkan kurang mendapat dukungan kader terdeteksi dini kanker serviks sebanyak 13 orang (46.4\%) dan yang tidak sebanyak 15 orang $(53.6 \%)$. Hasil uji statistik menggunakan chi-square menunjukkan terdapat hubungan yang signifikan antara dukungan kader terhadap terdeteksi dini kanker serviks dengan nilai $p$ value sebesar $0,002<0,05$.

Penelitian ini sejalan dengan teori bahwa Kader Kesehatan adalah perwujudan peran aktif masyarakat dalam pelayanan terpadu. Keaktifan kader kesehatan dapat diasumsikan bahwa kader kesehatan yang aktif melaksanakan tugasnya dengan baik sesuai dengan wewenang dan tanggung jawabnya, maka kader kesehatan tersebut termasuk dalam kategori yang aktif. Peran aktif kader dapat mempengaruhi mau atau tidaknya seseorang untuk melakukan deteksi dini kanker serviks. (Handayani, 2018).

Penulis menyimpulkan bahwa peran serta kader sangat diperlukan guna mengedukasi, memotivasi, serta meningkatkan minat WUS untuk melakukan pemeriksaan IVA. Hal ini dapat di realisasikan pada kegiatan warga seperti 
pertemuan RT, arisan, pengajian dan komunikasi secara personal ketika berkunjung kerumah WUS maupun secara tidak langsung melalui media sosial, selain itu juga diperlukan dukungan dari pengurus RT yang bertanggungjawab atas kinerja kadernya. Pencegahan kanker serviks dengan deteksi dini menggunakan IVA test yaitu memberi informasi tentang pemeriksaan IVA test serta mengajak WUS untuk melakukan pemeriksaan IVA test.

\section{KESIMPULAN}

Dari hasil pembahasan penelitian yang berjudul hubungan pendidikan, paritas dan dukungan kader dengan deteksi dini kanker serviks pada pemeriksaan IVA di Puskesmas Nagaswidak Palembang Tahun 2021 dapat di simpulkan sebagai berikut :

Ada hubungan pendidikan, paritas dan dukungan kader secara simultan dengan kejadian deteksi dini kanker serviks di Puskesmas Nagaswidak Palembang Tahun 2021

Ada hubungan pendidikan, paritas, dan dukungan kader secara parsial dengan kejadian deteksi dini kanker serviks di Puskesmas Nagaswidak Palembang Tahun 2021

\section{SARAN}

Bagi Puskesmas Nagaswidak Palembang adalah sebagai bahan evaluasi tenaga kesehatan untuk memberikan penyuluhan kapada wanita usia subur mengenai kesehatannya. Bagi Universitas Kader Bangsa Palembang adalah untuk meningkatkan kualitas mahasiswa dengan pengalaman melakukan penelitian serta tersedianya informasi yang di harapkan sebagai bahan pustaka bagi mahasiswa akademik kebidanan khususnya UKB. Bagi peneliti sendiri sebagai bahan masukan dan sarana bagi peneliti untuk meningkatkan wawasan dan pengetahuan tentang kanker serviks, serta menambah pengalaman dalam menerapkan ilmu yang telah didapatkan selama masa perkuliahan khususnya dalam pelaksanaan penelitian. Bagi peneliti yang akan dating diharapkan dapat melakukan penelitian lanjutan dan analisis yang lebih mendalam tentang faktor - faktor lain yang berhubungan dengan kejadian kanker serviks.

\section{DAFTAR PUSTAKA}

Arimurti, I. S., Kusumawati, N., \& Haryanto, S. 2020. Hubungan Pendidikan Dengan Perilaku Deteksi Dini Kanker Serviks Pada Wanita Di Kelurahan Kebon Kalapa Bogor. Edu Dharma Journal: Jurnal penelitian dan pengabdian masyarakat, 4(1), 10-18.

Ayudia, Vinny Nur. 2020. Faktor-faktor yang berhubungan dengan pemanfaatan IVA di Puskesmas Titi Papan Medan. Skripsi Sarjana[1798].

Bray F, Ferlay J, Soerjomataram I, Siegel RL, Torre LA, Jemal A. Global Cancer Statistics 2018: GLOBOCAN Estimates of Incidence and Mortality Worldwide for 36 Cancers in 185 Countries. CA Cancer J Clin. 2018;68(6):394-424.

Bermudez, A., Bhatla, N., \& Leung, E. 2015. Cancer of the cervix uteri. International Journal of Gynecology \& Obstetrics, 131, S88-S95.

Dalimartha, S., 2004. Kanker Serviks. In: Dalimartha, S., ed. Deteksi Dini Kanker \& Simplisia Antikanker. Jakarta: Penebar Swadaya, 14-18.

Dinas Kesehatan Provinsi Sumatera Selatan. 2016, 2017. Rekapitulasi Data Kejadian Kanker Serviks Sumatera Selatan. 
Dinas Kesehatan Kota Palembang. 2017 s.d 2020. Rekapitulasi Data Kejadian Kanker Serviks Sumatera Selatan.

Direktorat Pengendalian Penyakit Tidak Menular Kementerian Kesehatan RI. 2015. Panduan Program Nasional Gerakan Pencegahan dan Deteksi Dini Kanker Leher Rahim dan Kanker Payudara.

Fitrisia CA , Khambri D, UtamBI, Muhammad S. 2019. Analisis Faktorfaktor yang Berhubungan dengan Kejadian Lesi Pra Kanker Serviks pada Wanita Pasangan Usia Subur di Wilayah Kerja Puskesmas Muara Bungo 1. Jurnal Kesehatan Andalas. 2019; 8(4). http://jurnal.fk.unand.ac.id.

Globocan-IARC. (2018). Estimated cancer incidence, mortality and prevalence worldwide in 2018. International Agency for Reseach on canser, World health Organization. (2018).

International Agency for Research on Cancer (IARC). Globocan. 2018: Incidence, mortality, 5 years-Prevalence and new cases disability-adjusted life years (DALYs) cancer of the world. IARC Cancer Base.

KENDAL, D. B. 2017. Hubungan Usia, Paritas Dan Personal Hygiene Dengan Hasil Pemeriksaan Inspeksi Visual Asam Asetat (Iva) Di Puskesmas Brangsong 2 Kecamatan Brangsong Kabupaten Kendal. Jurnal Kebidanan, 6(2), 103-107.

Kemenkes RI. (2015). Infodatin "Situasi Penyakit Kanker". Pusat Data dan Informasi Kemenkes RI.
Kemenkes RI Direktorat Pengendalian Penyakit Tidak menular. (2015).Program Nasional Gerakan Pencegahan Dan Deteksi Dini Kanker Leher Rahim Dan Kanker Payudara. Buku Panduan Pelaksanaan IVASADANIS tahun 2015.pdf.

Kepmenkes. 2010. Keputusan Menteri Kesehatan Republik Indonesia Nomor: 796/MENKES/SK/VIII/2010 Tentang Pedoman Teknis Pengendalian Kanker Payudara dan Kanker Leher Rahim, Menteri Kesehatan Republik Indonesia, Jakarta.

Mawaddah. 2020. Implementasi Program Deteksi Dini Kanker Serviks dengan Metode IVA di Puskesmas Mulyorejo Kabupaten Deli Serdang Tahun 2020. Jurnal Bidan. http://repositori.usu.ac.id/handle/12345 6789/25329.

Nurlelawati, E., Devi, T. E. R., \& Sumiati, I. 2018. Faktor-Faktor yang Berhubungan dengan Kejadian Kanker Serviks di Rumah Sakit Pusat Pertamina Jakarta Tahun 2016. Jurnal Bidan, 4(1), 234022.

P Nurjanah, S. 2019. Faktor Yang Memengaruhi Wanita Usia Subur (Wus) Dalam Melakukan Iva Tes (Inspeksi Visual Asam Asetat) Di Wilayah Upt Puskesmas Sapat Kecamatan Kuindra Kabupaten Indragiri Hilir Provinsi Riau Tahun 2019 (Doctoral dissertation, Institut Kesehatan Helvetia).

Puspitaningrum, E. (2020). Rasio Prevalensi Paritas Terhadap Kejadian Kanker Serviks Di Kota Yogyakarta (Doctoral dissertation, Poltekkes Kemenkes Yogyakarta). 
Rambu, Aji. 2020. Faktor Risiko yang Berhubungan dengan Kejadian Lesi Prakanker Serviks di Puskesmas Bakunase Kota Kupang. Jurnal Kesehatan.

Http://ejurnal.Undana.Ac.Id/mkn.

Ramirez, P. T., Jhingran, A., Macapinlac, H. A., Euscher, E. D., Munsell, M. F., Coleman, R. L., \& Ramondetta, L. M. (2011). Laparoscopic extraperitoneal para-aortic lymphadenectomy in locally advanced cervical cancer 1: A prospective correlation of surgical findings with positron emission tomography/computed tomography findings. Cancer, 117(9), 1928-1934.

Rosdiana, M. (2019). Hubungan Antara Paritas Dan Pengetahuan Wanita Usia Subur Terhadap Pemilihan Metode Pap Smear Di Rumah Sakit Islam Siti Khadijah Palembang Tahun 2019. In Prosiding Seminar Nasional (pp. 106-113).

Rukiyah, A. Y., \& Yulianti, L. (2018). Asuhan Kebidanan Pada Ibu Masa Nifas. Jakarta: CV. Trans Info Media.

Savitri, A. 2015. Kupas Tuntas Kanker Leher Rahim. Jogjakarta. Pustaka Baru Press.

Setyani, R. A. (2018). Pemberdayaan Wanita Melalui Deteksi Dini Kanker Serviks. Jurnal Ilmiah Bidan, 3(2), 1216.

Suci Nurjanah. 2019. Faktor-Faktor yang mempengaruhi WUS dalam melakukan IVA Tes adalah pengetahuan, sikap, dukungan suami dan dukungan kader. Jurnal Bidan

$\begin{array}{cccc}\text { Sukaca,Bertiani. } 2009 . \quad \text { Cara } & \text { Cerdas } \\ \text { Menghadapi } & \text { kanker Serviks } & \text { (Leher } \\ \text { Rahim). Yogyakarta: Genius. } & \end{array}$

Wulan, A. R. (2019). Hubungan Dukungandengan Minat Wus (Wanita Usia Subur) Dalam Pemeriksaan Iva Test (Inspeksi Visual Asam Asetat) Di Dusun Milir Kecamatan Jimbaran Kabupaten Semarang (Doctoral dissertation, Universitas Ngudi Waluyo).

WHO. (2018). Cervical Cancer. http://www.who.int/ cancer/prevention/diagnosisscreening/cervicalcancer/en// 